\title{
Studies in comparative sugar preference in rodents: I. Methodology differences'
}

\author{
MAHLON W. WAGNER, ${ }^{2}$ VALPARAISO UNIVERSITY, \\ Valparaiso, Indiona
}

The glucose preferences of deer mice, Florida mice, and kangaroo rats were examined over $2 \mathrm{~h}$ and $24 \mathrm{~h}$. At the end of both periods Ss had greatest intake for the less sweet solutions. Citing other literature, it is shown that this is not a true measure of glucose preference, but an artifact of the method of testing.

In the study of the preferences, or incentive values, of sugar solutions several methods have been used and differing results have been obtained. Using short term (less then $2 \mathrm{~h}$ ) exposure to the sugar solution, using number or rate of bar pressing, or comparing two sugar solutions directly, it is generally found that the sweeter solution is preferred (Jacobs, 1962; Guttman, 1953; Wagner \& Rowntree, 1966a). When using long term (greater than $6 \mathrm{~h}$ ) exposure to sugar solutions or when pairing sugar with water, it is generally found that the sweetest solutions are less preferred (Jacobs, 1962; Hammer, 1967). There are conflicting results, however, which suggest that the differences in preferences are a result of the methods used (Stellar \& McCleary, 1952; Wagner, Green \& Manley, 1965). The above cited studies have generally used the traditional laboratory white rat.

It was the purpose of this study to compare different methods of presenting sugars over different periods of time to different species of rodents.

Method. Subjects were seven deer mice (Peromyscus leucopus), two Florida mice (Peromyscus floridanus) bred and reared at the Animal Behavior Laboratory at Michigan State University, and four Bannertail kangaroo rats (Dipodomys spectabilis) wildtrapped six months previously in Arizona. All Ss were housed individually with standard laboratory food and water always available.

All Ss were given choices of water and a $5,10,25$ or $37.5 \%$ anhydrous glucose solution (prepared on a weight-by-volume basis). From February 19 to March 12,1967, all Ss were exposed to the two choices for $2 \mathrm{~h}$ per day with each choice-pair being given four times. From March 13 to April 1, Ss were given $24 \mathrm{~h}$ exposure to a sugar solution and water with each concentration-choice presented four times on a randomly ordered schedule.

Results. In all species, Ss preferred the sugar solution to water regardless of glucose concentration; and the Florida mice drank most and the kangaroo rats drank least. Preferences are shown in Fig. 1.

2-h intake. Comparing the 2-h test with the first $2 \mathrm{~h}$ of the $24-\mathrm{h}$ test, intake was greater and preferences were more pronounced in the former. Preferences after $2 \mathrm{~h}$ of the 24-h test were not similar to those after the 2-h test. Maximal intake was for sweeter solutions in the 24-h test than in the 2-h test.

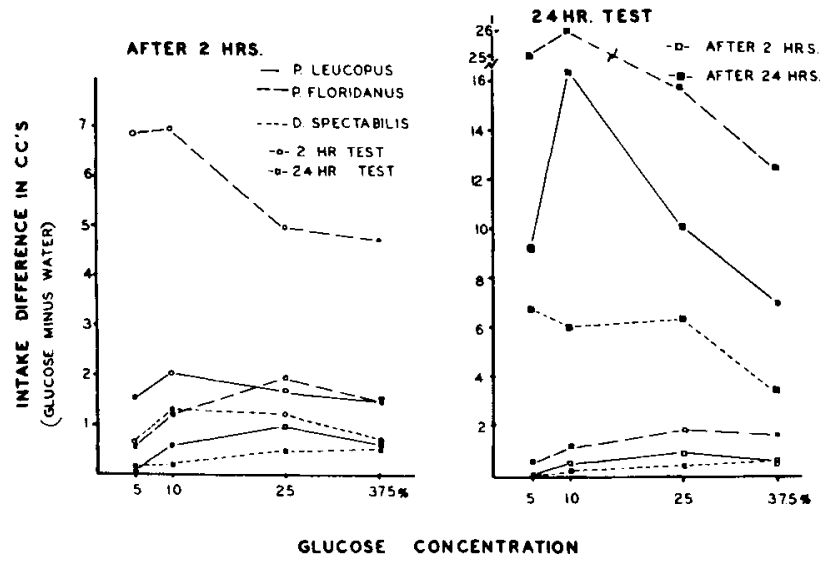

Fig. 1. Glucose preferences of rodents. 24-h test. Intake after $2 \mathrm{~h}$ of the 24 -h test do not predict maximal intake after $24 \mathrm{~h}$. Initially, sweeter solutions were drunk, but intake for the less sweet solutions increased more over the 24-h period. In addition, there were species differences in intake and in maximal intake (preference) after $24 \mathrm{~h}$.

$2-h$ vs $24-h$ tests. Although the preceeding analysis indicates disagreement of maximal intake, if we consider the preferences resulting from the 2 -h test to those resulting from the $24 \mathrm{~h}$ test, there is definite agreement. The Florida mice maximally preferred 5 and $10 \%$ solutions at the end of both tests and the deer mice showed the greatest preference for $10 \%$ glucose. Only the kangaroo rats had differing maximal preferences, drinking most from the 10 and $25 \%$ solutions after the 2 -h test and most from the 5,10 and $25 \%$ after the 24 h test.

Discussion. While the data presented here compare favorably with those of others who have examined the preferences of laboratory rats by pairing glucose with water, there is no agreement with the conclusions drawn by others. It is interesting to note that the preferences after $2 \mathrm{~h}$ of the 24-h test were neither indicative of final preference nor similar to preferences found in the 2-h test. McCleary's (1953) osmotic postingestion factor (where the animal avoids prolonged intake of hypertonic solutions which supposedly will dehydrate the body) is not supported by the data since Ss often went five or six consecutive days still drinking sugar solution with negligible water intake (usually averaging less than $1 \mathrm{cc}$ per day in the $24 \mathrm{~h}$ tests).

The preference for less sweet solutions seems to be an artifact of testing. If Ss are given a choice of two sugar solutions instead of sugar and water, there is a consistent preference for the sweeter of the two solutions regardless of concentration. This has been found for squirrel monkeys (Wagner et al, 1965), laboratory rats (Wagner, 1965), five species of deer mice (Wagner \& Rowntree, 1966b), and laboratory-adapted kangaroo rats (Wagner, 1967). It seems inappropriate to examine preferences by measuring solely intake unless the animal is actually given a choice, in this case, between two sugars and not between sugar and water. Wagner et al (1965) pointed out the dangers in using solely volume ingested to infer preferences by plotting intake data showing preference for less sweet glucose solutions when actually the monkeys were consistently preferring the sweeter solutions.

The species differences found here are primarily of a quantitive nature attributable to (1) greater overall intake by Florida mice (who are much larger than most deer mice) and (2) the lower intake and somewhat greater preference for sweeter solutions by kangaroo rats who had been wild-trapped and have basically different water balance mechanisms than rats or deer mice.

\section{REFERENCES}

GUTTMAN, N. Operant conditioning, extinction and periodic reinforcement in relation to concentration of sucrose used as a reinforcing agent. $J$. exp. Psychol., 1953, 46, 213-244.

HAMMER, LOIS R. Saccharin and sucrose intake in rats: long- and short-term tests. Psychon. Sci., 1967, 8, 367-368.

JACOBS, H. L. Some physical, metabolic, and sensory components in the appetite for glucose. Amer. J. Physiol., 1962, 203, 1043-1054.

McCLEARY, R. A. Taste and post-ingestion factors in specific hunger behavior. J. comp. physiol. Psychol., 1953, 46, 411-421.

STELLAR, E., \& McCLEARY, R. A. Food preference as a function of the method of measurement. Amer. Psychologist, 1952, 7, 256.

WAGNER, M. W. Satiation effects on rate of intake and preference of glucose solutions. J. comp. physiol. Psychol., 1965, 59, 115-117.

WAGNER, M. W. Comparative sugar preference in grasshopper mice and kangar oo rats. J. Mammalogy, 1967, 48, 324-326.

WAGNER, M. W., GREEN, K. F., \& MANLEY, M. B. Paired comparison method for measurement of sugar preference in squirrel monkeys. Science, $1965,148,1473-1474$.

WAGNER, M. W., \& ROWNTREE, J. T. Methodology of relative sugar preferences in laboratory rats and deer mice. J. Psychol, 1966a, 64, $151-158$.

WAGNER, M. W., \& ROWNTREE, J. T. Comparative sugar preference in various rodents. Amer. Zoologist, 1966b, 6, 536 .

NOTES

1. This research was supported by NIH grant No. MH 10185 to M. W. Wagner. 2. Now at State University College, Oswego. N. Y. 13126. 